\title{
Anopheles halophylus, a New Species of the Subgenus Nyssorhynchus (Diptera: Culicidae) from Brazil
}

\section{Teresa Fernandes Silva do Nascimento ${ }^{+}$, Ricardo Lourenço-de-0 liveira}

Departamento de Entomologia, Instituto Oswaldo Cruz-Fiocruz, Av. Brasil 4365, 21045-900 Rio de Janeiro, RJ, Brasil

Anopheles halophylus n.sp. is described from Central Brazil. It is distinguished from An. triannulatus (Neiva and Pinto) by morphological and morphometric characters, especially in the male genitalia, larva and egg. Illustrations of the male and female genitalia, egg, larva and pupa, and discussion of the status of names associated with An. triannulatus are provided.

Key words: Anopheles halophylus - new species - Anopheles triannulatus - taxonomy - Culicidae - Brazil

\begin{abstract}
Anopheles triannulatus is a small anopheline species belonging to subgenus Nyssorhynchus Blanchard, that was originally described by Neiva and Pinto (1922) from anomalous females captured at Fazenda São João, on the west bank of the Cuiabá River, in Central Brazil. It is commonly reported in anopheline surveys conducted both inside and outside forests in South America (Deane et al. 1948, Faran 1980, Faran \& Linthicum 1981, Charlwood \& Wilkes 1981, Lourenco-de-Oliveira et al. 1989, Rubio-Palis et al. 1992, Rubio-Palis 1994, Lourenço-de-Oliveira \& Luz 1996). It is widely distributed in South America East of the Andes including Argentina, Brazil, Paraguay, Bolivia, Guyana, Suriname, French Guyana, Colombia, Venezuela, Ecuador and Peru, and in Central America in Panama, Costa Rica and Nicaragua (Faran 1980, Faran \& Linthicum 1981). Since the 1920s, but particularly after the 1940s, An. triannulatus has been considered to be a polymorphic species (Pinto 1939, Galvão 1940, Galvão \& Lane 1941, Deane et al. 1947a,b, Forattini 1962, Faran 1980) or a complex of sibling species (Rosa-Freitas et al. 1998) because of morphological variations detected in adult and immature stages, especially in Brazil. The taxonomic status of the forms/varieties described as An. triannulatus 1.s. has never been adequately evaluated. Recent mosquito collections carried out at a locality in Central Brazil yielded specimens that are clearly distinct from An. triannulatus and are described here as new species.
\end{abstract}

\section{MATERIALS AND METHODS}

Terminology of morphological characters, abbreviations and counts of larval and pupal setae follow Harbach and Knight (1980), for wing spot nomenclature follows Wilkerson and Peyton (1990), and for the dorsal and ven-

This study was partially supported by Fundação de Amparo à Pesquisa do Estado do Rio de Janeiro (process E-29/170 205/ 90).

${ }^{+}$Corresponding author. Fax: +55-21-2573.4468. E-mail: tsilva@gene.dbbm.fiocruz.br

Received 10 May 2001

Accepted 12 June 2002 tral polarities of egg nomenclature follows Valle et al. (1999). Abbreviations used: G, genitalia; L, 4th instar larva; Le, larval exuvia; P, pupa; Pe, pupal exuvia. Range and modal number of setal branches for pupae and larvae are presented in Tables II and III respectively. At least 30 examples of each stage were examined for both morphometric and morphological analyses. Statistical analysis of morphometric data was done using the Student-NewmanKeuls test.

Progenies of females and immature stages of $A n$. triannulatus collected in 12 localities in Brazil, Argentina and Peru were included in the present study for morphological and morphometric comparisons. These localities included the type-locality of An. triannulatus, An. cuyabensis (Neiva and Pinto) [=An. triannulatus $]$ and $A n$. davisi Peterson and Shannon [=An. triannulatus]. To obtain progenies, females were blood fed and kept in individual oviposition vials. Eggs from each female were fixed and stored in $4 \%$ glutaraldehyde or alcoholic Bouin's solution for morphological analyses. Larvae from each progeny were separated into two groups: one allowed to develop to the adult stage and the other stored in $70 \%$ ethanol for morphological studies. Both Le and Pe from the former, with associated adults, were also preserved in $70 \%$ ethanol before mounting in balsam. Adults and immature stages from individual rearings were labeled with the same code as their mothers. The holotype is deposited at the Entomological Collection of Instituto Oswaldo Cruz (IOC), Rio de Janeiro. Paratypes are deposited in the collection of holotype, as well as at Faculdade de Saúde Pública, USP, São Paulo, Brazil (FSP-USP) and National Museum of Natural History, Washington, DC (NMNH).

\section{Taxonomic treatment}

Anopheles (Nyssorhynchus) halophylus sp.n. (Figs 1-4)

An. (Nys.) triannulatus triannulatus in part of Galvão, 1940: 410, 438, 440, 442, 476, 477, figs 42, 45; of Galvão and Lane, 1941: 14-17; of Galvão, 1943: 142, 146, 149-151; Lane, 1953: 275; Forattini, 1962: 402.

Female - Integument brown. Head: vertex with erect, spatulate, white scales changing to dark brown and with erect spatulate scales on occiput and postgena. Postgena with tuft of spatulate white scales on ventral median area close to gena. Interocular space with frontal tuft of long whitish setae and row of small, falcate white scales along ocular 
margin of eyes; each side of head with 7-9 $($ mean $=8)$ long, brown, ocular setae. Clypeus bare. Antenna pale brown, pedicel darkish brown, with small patch of white scales dorsally; flagelomere 1 with patch of long, slender white scales apically and smaller decumbent spatulate white scales near base. Maxillary palpus (Fig. 2) mostly dark brown; palpomeres 2 and 3 with incomplete apical white ring and few white scales mesally; palpomere 4 darkscaled at both basal and apical ends, with median patch of white scales covering $58-67 \%$ of dorsal, and part of outer surfaces; palpomere 5 entirely covered with white scales; length of maxillary palpus 1.3-2 $\mathrm{mm}($ mean $=1.8$ $\mathrm{mm})$. Proboscis with decumbent, dark brown, spatulate scales and small brown setae; ventrobasal surface with 37 long, dark brown setae; proboscis length $1.4-2 \mathrm{~mm}$ (mean $=1.7 \mathrm{~mm})$, proboscis $0.85-1.05($ mean $=0.95)$ length of maxillary palpus and 0.63-0.74 (mean $=0.68)$ length of forefemur; labela with short, dark brown setae. Thorax: integument dark brown, covered with silvery and darkish pollinosity and numerous long, dark brown setae. Scutum and scutellum almost completely covered with yellowish scales and a few whitish scales in some areas. Scutum with 3 small darkish spots on integument, 2 on dorsocentral area at posterior end of prescutal sutures, one in prescutelar

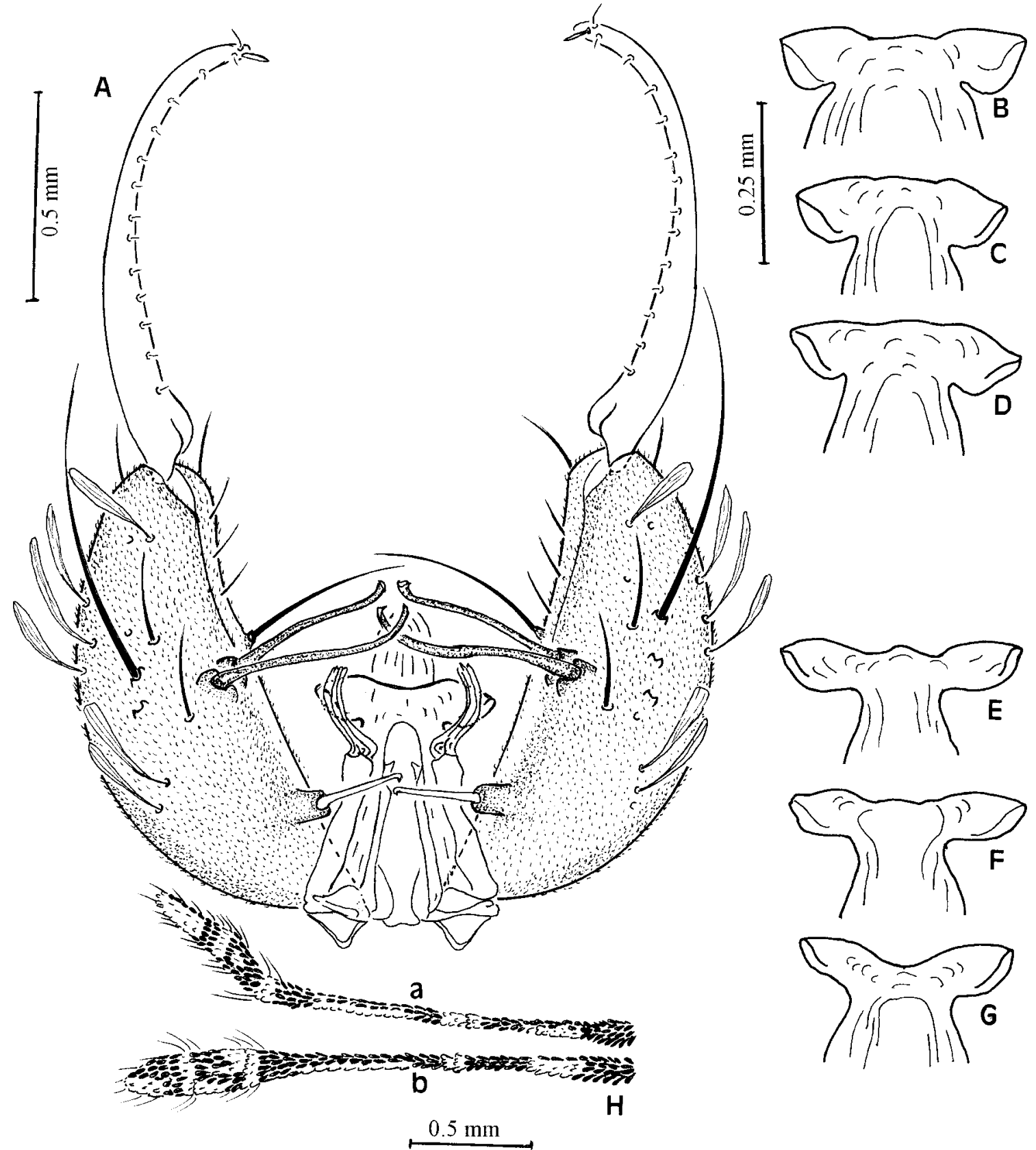

Fig. 1: Anopheles halophylus n. sp. A: male genitalia, dorsal aspect; B-D: ventral lobe of claspette; H: male: maxillary palpi, (a) dorsal aspect, (b) lateral aspect. An. triannulatus. E-G: ventral lobe of claspette. E: Fazenda São João (MT), type locality; F: Costa Marques (RO); G: Silva Jardim (RJ). 
area extending onto median lobe of scutellum; scutal setae numerous, dark brown; scutal pale scales fusiform; white scales on anterior promontory slender, piliform; acrostichal and dorsocentral areas with yellowish spatulate scales; median scutal fossa with scattered yellowish decumbent spatulate scales; anterolateral area of scutum with patch of broad, dark brown scales intermixed with a few pale scales; posterior area of scutum with spatulate, yellowish scales; lateral area of scutum with spatulate and fusiform white scales; antealar area with spatulate, white scales, and supraalar area with fusiform scales intermixed with spatulate white scales; lateral and median prescutellar area with fusiform, decumbent, yellowish scales. Scutellum with 7-10 short and 12-15 long, dark brown, evenly spaced setae, and with spatulate and falcate, decumbent, yellowish scales along posterior border. Antepronotum with long, brown setae with golden reflections and dark brown spatulate scales on upper region, with a few whitish scales posteriorly. Mesoposnotum with integument dark brown, bare. Pleural integument brown to dark brown, with pattern of pale spots produced by areas of silvery pollinosity, especially on ventral border of mesanepimeron and on lower mesokatepisternum; setae brown to dark brown with golden reflections. Upper proepisternal setae 1-3 (2), long, dark brown; prespiracular setae 1-2, very small, golden and postspiracular area bare; prealar setae 2-6 (5), long, brown, prealar area without scales; upper mesokatepisternal setae 2,3 (3), long, brown; small patch of spatulate, white upper mesokatepisternal scales; lower mesokatepisternal setae 1,2 (1), brown; a few spatulate, white lower mesokatepisternal scales; upper mesepimeral setae 2-6 (4), long, light brown, upper mesepimeral area without scales; anterior mesepimeral area with a few spatulate, white scales. Legs: mostly dark brownscaled; pale scales from yellowish white to white in colour; coxae and trochanters dark brown-scaled with spatulate, white scales at bases and apices of fore-, mid- and hindcoxae and apices of trochanters; patch of spatulate, dark brown scales on anterior surface of forecoxa, setae brown. Base of all femora and midtibia pale. Forefemur brown-scaled with stripe of white scales on ventrobasal area, ventral apex pale, some specimens with broad stripe of whitish scales dorsolaterally. Mid- and hindfemora brown scaled with ventral stripe of whitish scales, midfemur with 2,3 (2) spots of white scales at apex of dorsal surface, and 1,2 (1) on hindfemur, some specimens with narrow stripe of white scales on middorsal area. Fore-, mid- and hindtibiae brown-scaled with narrow ring of white scales at apex, with narrow stripe of white scales on middorsal surface, ventral surface pale. Fore-, mid- and hindtarsomeres 1 dark brown with ventral pale stripe and narrow ring of whitish scales at apex. Foretarsomere 2 dark brown with apical ring of whitish scales, tarsomere 3 with apical $0.29-0.55$ pale $($ mean $=0.44)$, tarsomeres 4 and 5 entirely dark, in a few specimens tarsomeres 4 and 5 with few whitish scales at apex (in $3.3 \%$ and $0.6 \%$ of specimens examined, respectively), pale scales on foretarsomere 4 are sometimes present in only one of the legs. Midtarsomere 2 dark brown with a few whitish scales dorsally, ring of pale scales at apex and sometimes with narrow stripe of pale scales ventrally; midtarsomere 3 dark brown, with a few whitish scales at apex, midtarsomeres 4 and 5 entirely brown ( 1 or 2 whitish scales present at apex of tarsomere 4 of 2 specimens examined). Hindtarsomeres 25 with snow-white scales; hindtarsomere 2 white-scaled on distal 0.41-0.58 $($ mean $=0.48)$, hindtarsomeres 3 and 4 entirely white (only one specimen with few pale brown scales at apex of hindtarsomere 4 ), hindtarsomere 5 palescaled on apical $0.48-0,86($ mean $=0,59)$. Wing (Table I): length 2.28-3.20 mm (mean = 2.84); dark scales dark brown; pale scales white. Basal pale spot plus prehumeral pale spot $0.10-0.22 \mathrm{~mm}($ mean $=0.17)$; basal dark spot absent; humeral pale spot 0.05-0.14 mm $($ mean $=0.09)$, usually smaller than prehumeral dark $(0.13-0.26 \mathrm{~mm})(\mathrm{HP} / \mathrm{PHD}=$ $0.20-0.75$; mean $=0.46$ ); presector pale spot usually present (absent in one specimen examined); accessory sector pale spot present in $51.8 \%$ of specimens examined; subcostal pale spot small $(0.05-0.16 \mathrm{~mm}$; mean $=0.10)$, smaller than sector dark spot $(\mathrm{SCP} / \mathrm{SD}$ ratio $=0.15)$; preapical pale spot small, almost 0.2 length of preapical dark spot in $26 \%$, and around 0.5 of preapical dark spot in $18.5 \%$ of specimens examined; apical dark spot usually longer than preapical pale $(\mathrm{AD} / \mathrm{PP}$ ratio $=0.53-3$; mean $=1.28)$. Vein $\mathrm{R}_{\mathrm{s}}$ mostly dark-scaled, with one small white spot on proximal 0.3 ; distal dark spot of $\mathrm{R}_{\mathrm{S}}$ contiguous with first dark spot of $\mathrm{R}_{2}+\mathrm{R}_{3}$ in $14 \%$ of specimens examined; $\mathrm{R}_{2}+\mathrm{R}_{3}$ with subequal dark spots at both proximal and distal ends dorsally; $\mathrm{R}_{2}$ mostly dark-scaled, entirely dark in few specimens; $\mathrm{R}_{3}$ with three dark spots (entirely dark-scaled in one of the specimen examined); $R_{4}+R_{5}$ with dorsal patches of dark scales at proximal and distal ends; vein $\mathrm{M}$ mostly dark-scaled, $\mathbf{M}_{1+2}$ with alternating pale and dark spots dorsally or entirely dark; $M_{1}$ with dark spots close to both proximal and distal ends, proximal dark spot smaller than distal spot (in $27 \%$ of specimens examined these spots are of same size); $\mathrm{M}_{2}$ mostly dark-scaled, with 1 pale spot at proximal and distal ends; $\mathbf{M}_{3+4}$ mostly pale-scaled dorsally with 3 spots of dark scales: 2 small dark spots proximally and one large spot distally, this spot is twice length

\section{TABLE I}

Anopheles halophylus descriptive statistics for costal wing spot length $(\mathrm{mm})$ of female and male

\begin{tabular}{lcclll}
\hline & \multicolumn{2}{c}{ Female } & & \multicolumn{2}{c}{ Male } \\
\cline { 2 - 3 } \cline { 5 - 6 } Wing spot & Range & Mean & & Range & Mean \\
\hline Basal pale (+PHP) & $0.10-0.22$ & 0.17 & & $0.06-0.20$ & 0.15 \\
Prehumeral dark & $0.13-0.26$ & 0.20 & & $0.14-0.38$ & 0.21 \\
Humeral pale & $0.05-0.14$ & 0.09 & & $0.04-0.18$ & 0.11 \\
Humeral dark & $0.12-0.20$ & 0.16 & & $0.12-0.22$ & 0.18 \\
Presector pale & $0.03-0.11$ & 0.07 & & $0.02-0.12$ & 0.07 \\
Presector dark & $0.20-0.52$ & 0.34 & & $0.27-0.48$ & 0.38 \\
Sector pale & $0.04-0.20$ & 0.08 & & $0.02-0.20$ & 0.13 \\
Accessory sector dark & $0.02-0.13$ & 0.08 & & $0.04-0.12$ & 0.07 \\
Accessory sector pale & $0.02-0.12$ & 0.08 & & $0.04-0.12$ & 0.08 \\
Sector dark & $0.50-0.76$ & 0.63 & & $0.44-0.62$ & 0.52 \\
Subcostal pale & $0.05-0.16$ & 0.10 & & $0.07-0.14$ & 0.11 \\
Preapical dark & $0.38-0.94$ & 0.63 & & $0.44-0.66$ & 0.52 \\
Preapical pale & $0.06-0.22$ & 0.14 & & $0.10-0.24$ & 0.16 \\
Apical dark & $0.08-0.26$ & 0.15 & & $0.08-0.16$ & 0.13
\end{tabular}

( $n=30$ wings from 30 individuals); PHP: prehumeral pale 
of median dark spot; $\mathrm{CuA}$ mostly white-scaled dorsally with 2 small dark spots: 1 proximal to bifurcation of vein $\mathrm{M}_{3+4}$ and 1 on proximal end of vein; 1A pale with 2 dark spots close to proximal and distal ends of vein. Pale fringe spots at ends of veins $R_{1}, R_{2}, R_{3}, M_{1}, M_{2}, C u A$ and $1 A$. Halter: scabellum with pale integument, without scales; pedicel and capitellum with dark brown integument, dark brown-scaled dorsally and white-scaled ventrally. Abdo-
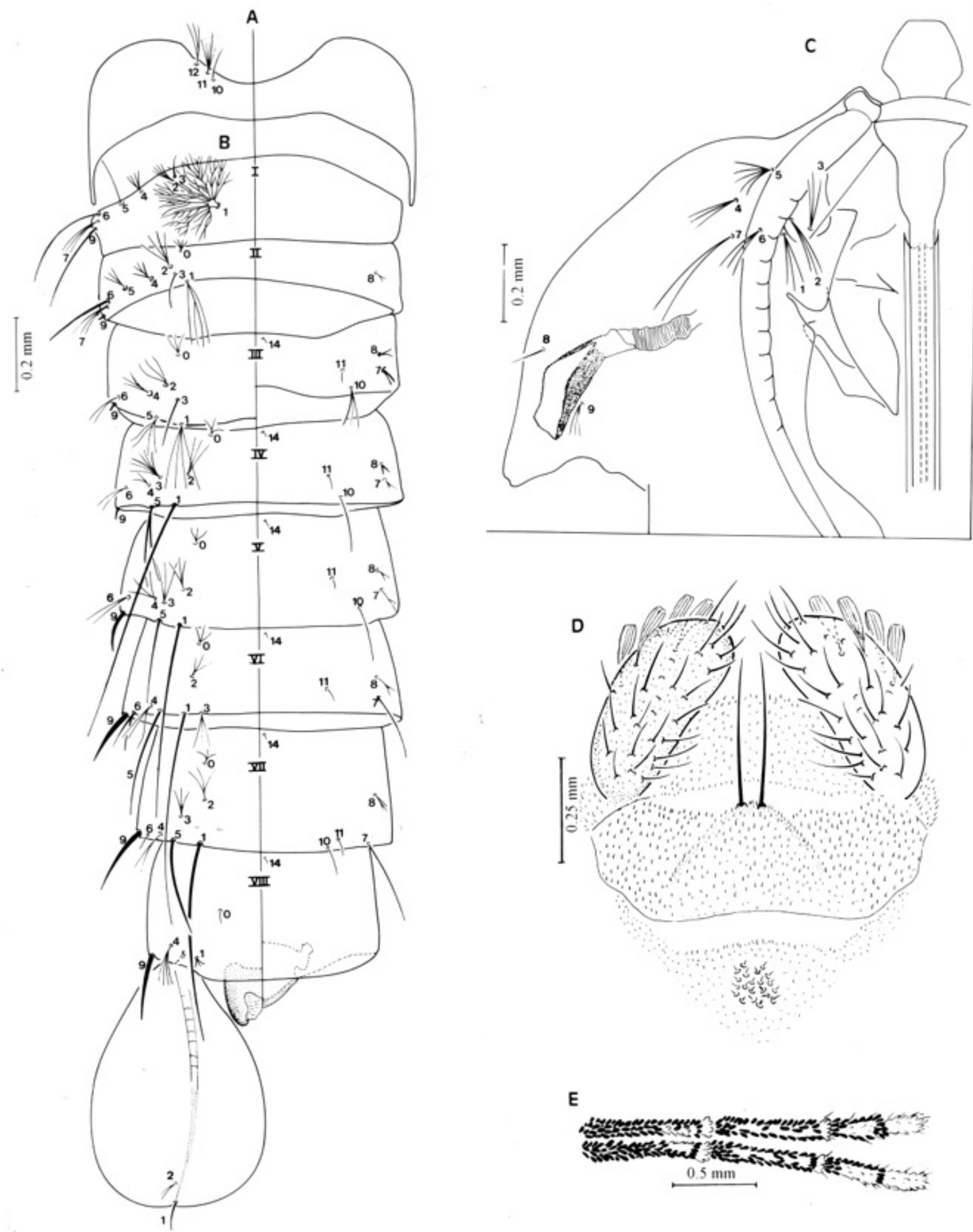

E

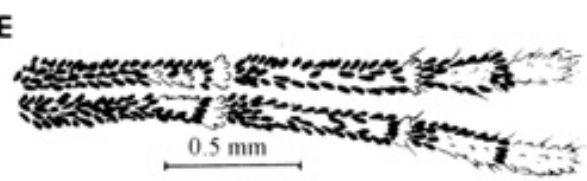

Fig. 2: Anopheles halophylus n. sp., pupa. A: metathorax; B: abdomen, left side dorsal, right side ventral; C: cephalothorax; D: female genitalia, ventral aspect; E: female maxilary palpus, dorsal aspect. 
men: integument dark brown. Terga with numerous long, dark brown setae. Terga II-VII with posterolateral tufts of broad erect spatulate dark scales and distal median patches of yellowish scales in roughly triangular shape; tergum VIII entirely covered with yellowish scales, intermixed with posterolateral dark scales. Sterna with scattered brown setae and spatulate white scales; white scales of sternum broader and less abundant than those on terga I-VII. Sternum I with 2 patches of few spatulate, white scales posterolaterally; sterna II-VII with 2 mesal patches of broad, spatulated white scales; posterolateral area with group of broad, dark brown spatulate scales; sternum VIII mostly covered with broad dark brown scales and 2 lateral patches of white scales at apex and base. Genitalia (Fig. 2): tergum IX narrow, spiculose; cerci elongate covered with minute spicules, setae moderately long; ventrolateral scales yellowish, dorsal scales dark brown; postgenital lobe weakly sclerotized, nearly triangular, caudal margin slightly rounded with 2 strong setae inserted close together, these setae shorter than length of cercus; insula spiculose with 21-30 small insular setae.

Male. Similar to female except for sexual and few other differences as follow. Head: antenna with flagellomeres pale with integument brown at base, setae light brown; flagellomere 1 with long, slender, white scales at dorsomesal surface and small, spatulate, dark brown scales at ventromesal surface. Maxillary palpus (Fig.1): dark brown, 2-2.4 $\mathrm{mm}($ mean $=2.2 \mathrm{~mm})$; 0.95-1.04 $($ mean $=0.99)$ length of proboscis; apex of palpomere 3 and all 4 and 5 enlarged; palpomere 2 essentially dark with few white scales dorsolaterally, mostly on proximal 0.3 , and white scales apically extending onto base of palpomere 3 ; palpomere 2 with erect, spatulate dark brown scales at base; palpomere 3 with white scales basally and narrow stripe of white scales dorsomesally; palpomere 4 with two bands of white scales, one basal and another at apex, mesobasal setae whitish; palpomere 5 with white scales dorsolaterally on distal 0.6 , essentially dark-scaled ventrally. Proboscis: length $2-2.4 \mathrm{~mm}($ mean $=2.2 \mathrm{~mm})$, with small dark brown scales and 5-9 $($ mean $=6)$ ventrobasal long, brown setae; labela brown with small pale brown setae. Legs: foreungues with a curved median tooth, about 0.25 length of foreungues. Wing (Table I): length 2.4-2.96 $\mathrm{mm}($ mean $=2.76 \mathrm{~mm})$. Accessory sector pale spot present in about $30 \%$ of the specimens examined. Genitalia (Fig. 1): ninth tergal lobe large covered with minute spicules. Gonocoxite elongate with minute spicules, dorsolateral surface with numerous spatulate, broad scales and long, strong setae; ventral surface with shorter but moderately long setae, smaller than accessory setae and longer than parabasal seta; inner surface with numerous moderately long setae; parabasal lobe moderately developed, parabasal seta sinuous, 0.15 distance from base of gonocoxite, stout with hooked tip, borne on tubercle; two strong sinuous accessory setae, with hooked tips, borne on strong tubercles, the most proximal and dorsal accessory seta longer and slightly stouter than other; internal seta slender, long, slightly curved. Dorsal lobe of claspette elongate with three foliaceous filaments at apex; ventral lobe of claspette fused, bare; basal lobe of ventral claspette moderatelly large, truncated and rugose, apicolateral margins of ventral claspette produced into wide, striated, auriculate, laterally and basally projecting lobes; gonostylus slightly longer than gonocoxite (1.03 of gonocoxite length), with minute preapical external seta and row of very small setae (9-14) on inner surface; gonostylar claw short, spiniform and blunt; aedeagus longer than wide (length/width ratio $=1.7$ ), hyaline, apex somewhat rounded in outline.

Pupa (Fig. 2). Position and development of setae as figured; range and modal number of branches in Table II. Integument pale, slightly more pigmented on metathoracic wing, articulations of antennal flagellomeres, abdominal segments I-IV and genital lobe. Cephalothorax: trumpet angusticorn, more pigmented than integument of cephalothorax, surface reticulated, paler and slightly less reticulated at base; trumpet index 3.3-6.2 (mean = 4.3); meatus $0.19-0.29($ mean $=0.26)$ length of trumpet. Abdomen: seta

TABLE II

Pupal setal branching for Anopheles halophylus: range (mode)

\begin{tabular}{|c|c|c|c|c|c|c|c|c|c|c|}
\hline \multirow[b]{2}{*}{ Seta } & \multirow[b]{2}{*}{ Cephalothorax } & \multicolumn{8}{|c|}{ Abdominal segments } & \multirow[b]{2}{*}{ Paddle } \\
\hline & & I & II & III & IV & $\mathrm{V}$ & VI & VII & VIII & \\
\hline 0 & - & - & $2-4$ & $2-5(3)$ & $2-4(3)$ & $2-4(3)$ & $2-5(3)$ & $2-5(3)$ & $1,2(1)$ & - \\
\hline 1 & $2,3(3)$ & $15-25(18)$ & $4-10(4)$ & $3-7(4)$ & 1 & 1 & $1,2(1)$ & 1 & $2-4(3)$ & 1 \\
\hline 2 & $2,3(3)$ & $2-4(4)$ & $2-5(4)$ & $3-5(3)$ & $2-4(2)$ & $2,3(3)$ & $1-3(2)$ & $1-3(2)$ & - & $1-3(2)$ \\
\hline 3 & $2-4(3)$ & 1 & 1 & 1 & $2-7(6)$ & $2-4(3)$ & $1-3(2)$ & $2,3(3)$ & - & - \\
\hline 4 & $3,4(3)$ & $3-6(4)$ & $2-4(4)$ & $2,3(2)$ & $1-3(2)$ & $2-4(3)$ & $1-3$ & $1-3(2)$ & $2-4(3)$ & - \\
\hline 5 & $3-5(5)$ & 1 & $2-4(3)$ & $3-6(4)$ & $1,2(2)$ & 1 & 1 & 1 & - & - \\
\hline 6 & $2-4(3)$ & 1 & $1,2(1)$ & $1-3(2)$ & $1,2(1)$ & $1,2(2)$ & $1,2(2)$ & $1,2(1)$ & - & - \\
\hline 7 & $2-4(2)$ & 3,4 & $3,4(3)$ & $2-4(2)$ & $2,3(2)$ & $2-4(2)$ & 1 & $1,2(1)$ & - & - \\
\hline 8 & 1 & - & 2 & $2,3(2)$ & $1-3(2)$ & $1-3(2)$ & $2,3(2)$ & $2-4(3)$ & - & - \\
\hline 9 & $2,3(3)$ & 1 & 1 & 1 & 1 & 1 & 1 & 1 & 1 & - \\
\hline 10 & $1,2(1)$ & - & 1,2 & $2,3(3)$ & $1-3(1)$ & $1,2(1)$ & - & $1,2(1)$ & - & - \\
\hline 11 & $2-5(4)$ & - & - & 1 & $1,2(1)$ & 1 & $1,2(1)$ & 1 & - & - \\
\hline 12 & $2,3(3)$ & - & - & - & - & - & - & - & - & - \\
\hline 14 & - & - & - & 1 & 1 & 1 & 1 & 1 & 1 & - \\
\hline
\end{tabular}

Based on counts made on 30 setae. 
1-IV-VII well developed, seta 1-IV 1.4 length of segment V; 8-II usually absent, often only alveolus present; 9-I single, long and thin, not aciculate; 9-II-VIII thorn-like to long and pointed; 9-II,III minute; 9-IV thick, 3.0 length of 9-III; 9-V-VIII strong, slightly curved; 9-V 4.5 length of 9IV; 9-VI 1.16 length of 9-V; 9-VII 1.07 length of 9-VI; 9-VIII occasionally forked, 0.96 length of 9-VII; 9-IV 0.09 length of segment; 9-V 0.42 length of segment; 9-VI 0.47 length of segment; 9-VII 0.46 length of segment and 9-VIII 0.39 length of segment. Paddle: large, length $0.62-0.77 \mathrm{~mm}$ $($ mean $=0.70 \mathrm{~mm})$, width $0.39-0.52 \mathrm{~mm}($ mean $=0.44 \mathrm{~mm})$, length/width ratio 1.4-1.8 (mean = 1.6), weakly pigmented, truncate; midrib distinct, extending almost to apex; external margin spiculose, spines more developed at apex; seta 1-P single, moderately developed, $2-\mathrm{P}$ shorter and less developed than 1-P.

Larva (Fig. 3) - Position and development of setae as figured; range and modal number of branches in Table III. Body nearly uniformly greenish in life, with small whitish dots on abdomen, which become gradually more conspicuous on sides of the posterior abdominal segments. Head: integument brown with irregular dark spots. Antennal length $0.20-0.22 \mathrm{~mm}$ (mean $=0.21 \mathrm{~mm}$ ), straight, darker than head integument, with short spicules, more numerous and developed on distal 0.6, anterior to base of seta 1-A; basal and ventral surfaces of antenna with scattered, short spicules; seta 1-A with 3-6 branches, inserted 0.05$0.08 \mathrm{~mm}$ (mean $=0.05 \mathrm{~mm}$ ) from base of antenna; setae 2,3A strong, spiniform and long; 2-A slightly longer than 3A, fringed in one side; 4-A thin and long with 2,3 (2) branches; 5,6-A small, strong and spiniform. Collar strongly pigmented; hypostomal suture incomplete. Dorsomentum with 3,4 lateral teeth on each side of central more developed tooth; ventromentum less pigmented than dorsomentum with 4 lateral teeth and 2 central more developed teeth; 2,3-C single, aciculate; $2-\mathrm{C} 1.2-1.4$ length of 3-C; clypeal index 1.3-2.0 (mean = 1.9); 6-Mx with 8 branches; 4-C with 2-4 (3) branches arising at different sites; 5-7-C plumose, 5-C usually in line with 6-C; 6-C sometimes slightly posterior to $5-\mathrm{C}$; 7-C anterior to 5,6-C; 8-C usually double; $9-\mathrm{C}$ almost in line with $10-\mathrm{C}$, with $2-5$ (3) branches, 9-C arising anterior to and slightly less developed than 8-C. Thorax: somewhat rounded in outline, bare; 1-3- $\mathrm{P}$ arising from distinct tubercles; $1-\mathrm{P}$ with 13-20 (16) filamentous branches; 2-P plumose, arising from strongly sclerotized tubercle; 3-P single; 5,6-P, 9-12-P and 9-12-M,T borne on common, sclerotized tubercles; 8-P,M,T, 4-7-P and 5-7-T borne on individual sclerotized tubercles; setal support plate spine more developed on mesothorax than on other thoracic segments. Abdomen: integument hyaline, slightly more spiculose on ventral surface on segments III-X, spicules more developed on segments VII and VIII. Seta 1-I-VII palmate with 12-31 foliaceus branches, 1-I less developed than 1-II-VII; 1-II-VII well developed, leaflets broad, smooth, with truncate tips; seta 6-I-III plumose, 6-IV-VI single, 6-VII with 5 branches; segment $X$ strongly spiculose, spicules more developed on distal edge; $4-X$ with 8 pairs of plumose setae. Saddle incomplete, spiculose; seta 1-X inserted on saddle. Spiracular apparatus: lateral arms of median plate variable developed, from rudimentary to completely absent, lat- eral arms pointed towards back, usually forming an acute angle with median plate, distance between apices of lateral arms $0.05-0.075 \mathrm{~mm}$ (mean $=0.05 \mathrm{~mm}$ ). Pecten with 1417 (mean $=15$ ) elongate, slightly recurved spines, pecten spines with minute spicules on basal $0.6 ; 3,4$ pecten spines more developed than others.

Egg (Fig. 4) - Broadly boat-shaped in both dorsal and lateral view, slightly wider at anterior end. Floats moderately wide, not overlapping on dorsal midline, positioned mediolaterally; length about $60 \%$ (range $55-61 \%$ ) of total egg length. Proportion of deck covered by floats invariable in egg batches from same female. Anterior and posterior deck enclosed by frill. Deck area occupying around $50 \%$ of dorsal surface, moderately wide on central area and much wider on both anterior and posterior ends; anterior deck wider than posterior deck. Anterior end broadly rounded; micropylar collar irregular in outline with 6-8 (6) radial rays; posterior end somewhat pointed.

Distribution - An. halophylus n.sp. is known only from the type-locality.

Bionomics - An. halophylus n. sp. seems to be exophilic and zoophilic, although it may bite man. During mosquito collections carried out in Salobra at sunset in an open area, simultaneously on horse and man, about 10 times more females of An. halophylus were collected feeding on a horse than on human bait. An. triannulatus-like females, including those of An. halophylus, were the first anopheline species collected on both horse and man at sunset. In fact, they started biting before sunset, in the daylight, and became rare or even disappeared 15-20 min after sunset, at which time other anophelines and culicines were still very numerous and active. An. halophylus is not involved in human malaria transmission. Its breeding sites are similar to those of An. triannulatus. Immature stages of An. halophylus were collected in swamps and temporary lakes formed during the flooding of the Miranda River. These breeding places were in full sun, rich in floating vegetation, especially Salvinia spp. Chemical analyses of the water of one breeding place showed a high concentration of sodium chloride (from 2 to $4 \mathrm{mg} / \mathrm{l}$ ). It was noted that when eggs laid by An. halophylus were maintained in tap water, most of the larvae died in the first and second instar, whereas An. triannulatus s.s. developed to the 4th instar and pupated. The immature stages of An. halophylus were successfully reared in filtered water taken from its breeding places.

Type material - Holotype male (no. 1647) with associated larval and pupal exuviae and male genitalia mounted on microscope slide, from the progeny brood of a female collected on horse bait, as follows: Salobra $\left(20^{\circ} 12^{\prime} 40^{\prime \prime} \mathrm{S}, 56^{\circ}\right.$ 29'30'W), State of Mato Grosso do Sul (MS), Brazil, 28VIII-1996, RS Souza coll., deposited at IOC, Rio de Janeiro. Paratypes: 51 specimens consisting of 5 females, 12 males, 12 larval exuviae, 8 pupal exuviae, 10 male genitalia from Salobra (MS), Brazil, as follows: 27-VII-1995, R Lourençode- Oliveira coll., 1E PeLe, 1G PeLe GG, 1G GG; 28-VIII1996, RS Souza coll., 1G PeLe GG, 1E Le, 1G Le GG, 1G GG, 1G Le GG, 1G GG, 1E, 1G PeLe GG, 1E PeLe, 1ELe, 1G GG, 1G PeLe GG; 29-VII-1997, R Lourenço-de-Oliveira and TFS Nascimento coll., 1G PeLe, 1G PeLe. Paratypes are deposited at IOC, FSP-USP and NMNH. 
Other material examined: An. halophylus n.sp. 248 adult specimens, 170 males, 72 male genitalia, 78 females, 40 female genitalia, 233Le, 180Pe, 32L, as follows: BRAZIL. Salobra (MS), 65 progeny broods from females collected on human and animal baits, as follows: 9-VII-1991, R

Lourenço-de-Oliveira coll., 18G, 8E, 10Le, 10Pe, 5GG, 2GE,

10L; 27-VII-1995, R Lourenço-de-Oliveira coll., 21 G, 4E,

20Le, 18Pe, 8GG; 5L; 1-VIII-1996, RS Souza coll., 4G, 4E,

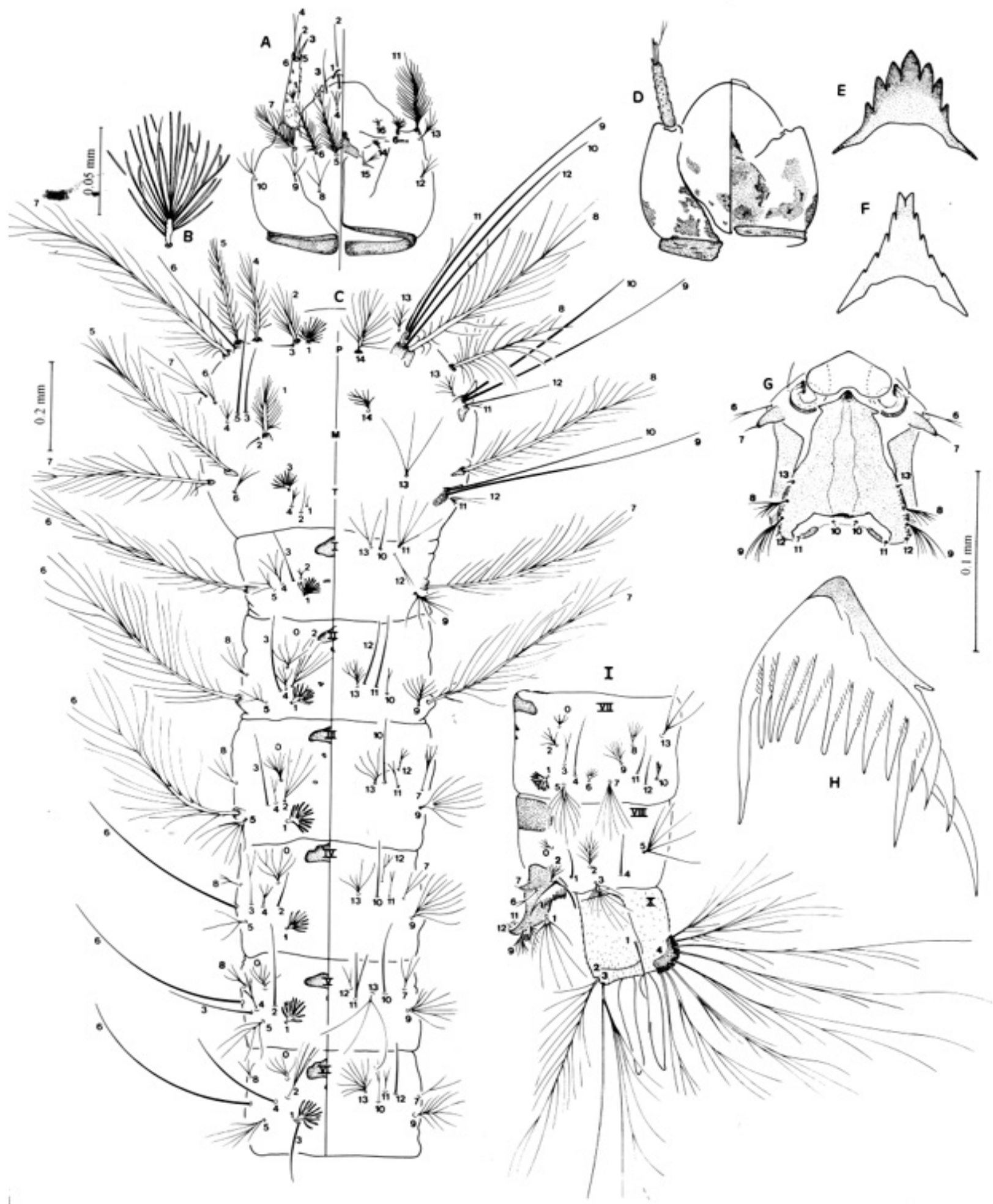

Fig. 3: Anopheles halophylus n. sp., larva. A: head, left side dorsal, right side ventral; B: detail of seta 1-P; C: thorax and abdominal segments I-VI, left side dorsal, right side ventral; D: head spots, left side dorsal, right side ventral; E: dorsomentum; F: vetromentum; G: dorsal aspect of spiracular apparatus; H: pecten and pecten plate; I: abdominal segments VII-X, lateral view. 


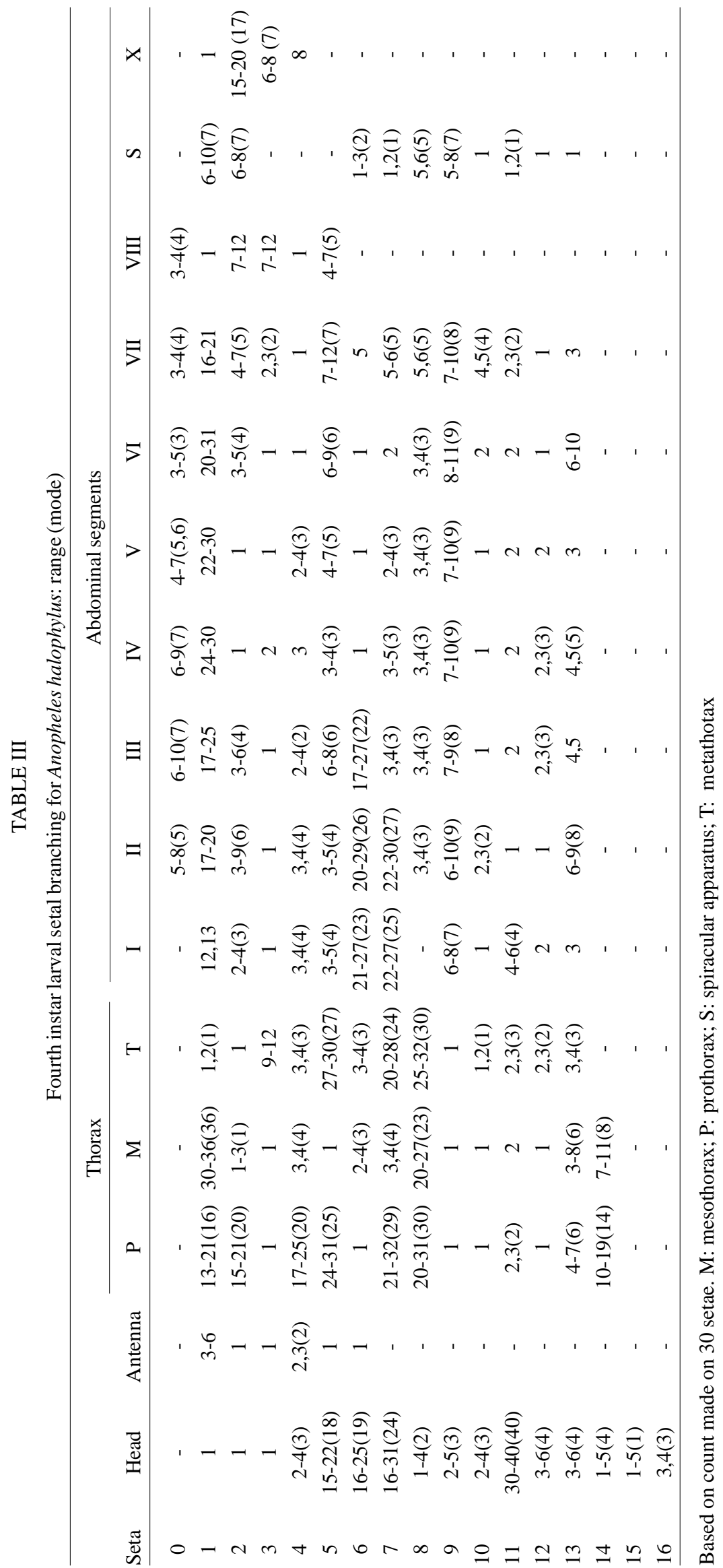


8Le, 6Pe, 3GG; 28-VIII-1996, same data, 78G, 33E, 74Le, 28Pe, 25GG, 10GE, 12Le; 29-VII-1997, R Lourenço-deOliveira and TFS Nascimento coll., 29G, 11E, 92Le, 85Pe, 13GG, 17GE, 3L; 11-IX-1998, R Lourenço-de-Oliveira coll., $12 \mathrm{G}, 15 \mathrm{E}, 18 \mathrm{Le}, 22 \mathrm{Pe}, 10 \mathrm{GG}, 11 \mathrm{GE} ; 18$ females deriving from fourth-instar larvae collected in breeding places, 9VII-1991, R Lourenço-de- Oliveira coll., 8G, with PeLe and male genitalia associated and $3 \mathrm{E}$ with PeLe associated.

An. triannulatus 347 males, 142 GG, 300 females, 99 GE, 549Le, 613Pe, 156G, as follows: BRAZIL. holotype female (n. 2026-IOC) and three additional females (n.1174, 1214 and 1252-IOC), Fazenda São João (16 57’30”'S, $56^{\circ}$ 36 '40"W), State of Mato Grosso (MT), VI-1922, C Pinto coll.; 7-10-IV-1990, same data, TFS Nascimento and E Duarte colls., 20 progenies from females collected on human bait, as follows: $28 \mathrm{Le}, 35 \mathrm{Pe}, 25 \mathrm{~L}, 16 \mathrm{G}, 25 \mathrm{E}, 18 \mathrm{GG}$, 4GE; 3-4-VII-1990, JBP Lima coll., 53L, 34Le, 67Pe; 31-VII1997, R Lourenço-de-Oliveira and TFS Nascimento colls., 10 progenies from females collected on horse bait, as follow: 47Le, 20Pe, 18L, 16G, 25E, 8GG, 10GE; Salobra (MS), 9-11-VII-1991, R Lourenço-de-Oliveira coll., 20 progenies from females collected on horse bait, as follows: $35 \mathrm{G}, 21 \mathrm{E}$, 36Le, 18L, 48Pe, 20GG, 15GE; 27, 28-VII-1995, 18 progenies, same data, as follows: $28 \mathrm{G}, 19 \mathrm{E}, 41 \mathrm{Le}, 58 \mathrm{Pe}, 20 \mathrm{GG}$, 16GE; 16-V-1996, RS Souza coll., 2 progenies, same locality, as follows: 8G, 6E,12Le, 11Pe; 18-VI-1996, 11 progenies, same data, as follows: $10 \mathrm{G}, 9 \mathrm{E}, 59 \mathrm{Le}, 55 \mathrm{Pe}, 14 \mathrm{GG}$; Costa Marques, State of Rondônia, JBP Lima, T Klein

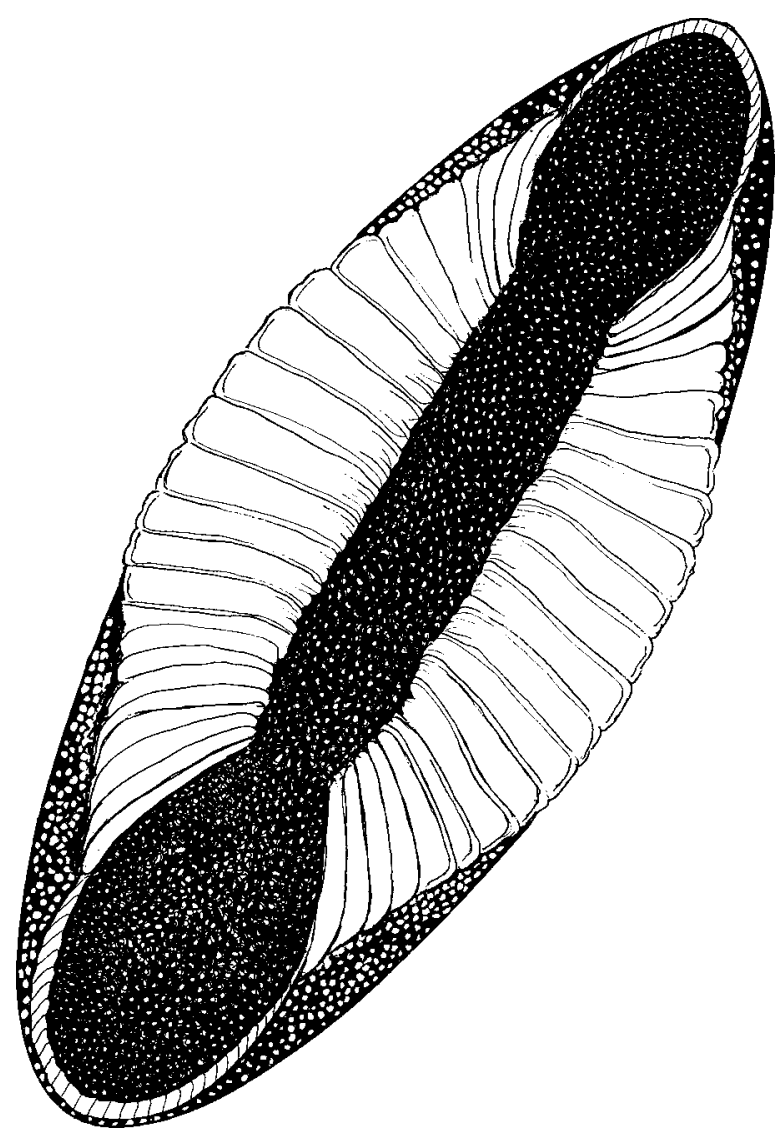

Fig. 4: Anopheles halophylus n. sp. Entire egg, dorsal (upper) view, anterior end at top. and TFS Nascimento colls., 1-IV-1989 and 30-III-1990, 20 progenies from females collected on human bait, as follows: 19G, 30E, 25Le, 43Pe, 30L, 12 GG, 9GE; Belém, State of Pará, 19,20-VIII-1991, J Conn, P Lounibous, TFS Nascimento colls.; 28 progenies from females collected on buffalo, as follows: 43G, 23E, 96Le, 59Pe, 25GG, 16GE; Peixoto Azevedo, State of Mato Grosso, VII-1996, JBP Lima coll., 6-XI-1998, R Lourenço-de-Oliveira and P Lounibos colls., 15 progenies from females collected on horse and human bait, as follows: $20 \mathrm{G}, 15 \mathrm{E}, 25 \mathrm{Le}, 38 \mathrm{Pe}$, 5GG, 2GE; Itaguaí, State of Rio de Janeiro (RJ), 28-X1992, SLB Luz coll., 1 progeny from female collected on horse bait, as follows: 5G, 3E, 2Le, 2Pe; Silva Jardim (RJ), 2-III-1998, CF Mendoza coll., 10 progenies from females collected on cow bait, as follows: $23 \mathrm{G}, 18 \mathrm{E}, 15 \mathrm{Le}, 19 \mathrm{Pe}$, 10GG, 8GE; Itapira, State of São Paulo, 10-X-1993, MA Motta, CF Mendoza, NA Honório, DC Lima colls., 5 progenies from females collected on human and cow baits, as follows: 18G, 10E, 19Le, 21Pe, 5GG, 2GE; Linhares, State of Espírito Santo (ES), 3-IV- 1996, CF Mendoza coll., 11 progenies from females collected on cow bait, as follows: 21 G, 26E, 22Le, 42Pe, 3GG, 2GE; State of Maranhão (MA), 16-X-1993, RL Oliveira coll., 3 progenies broods from females collected on horse bait, as follows: $12 \mathrm{G}, 2 \mathrm{E}, 18 \mathrm{Le}$, 12Pe, 1GG; Goiânia, State of Goiás, VII-1995, RL Oliveira coll., 3 progenies from females collected on horse bait, as follows: 12G, 11E, 15Le, 17Pe, 3GG, 2GE. PERU: Munichis (05 53 'S, $\left.76^{\circ} 12^{\prime} \mathrm{W}\right)$, Iquitos, Loreto Department, Province of Yurimaguas, I-1996, 1999, CF Mendoza coll., 25G, 13E, 15Le, 21Pe, 4GG, 3GE. ARGENTINA: Embarcación $\left(23^{\circ} 15^{\prime} 30^{\prime \prime} \mathrm{S}, 64^{\circ} 04^{\prime} 50^{\prime}\right.$ 'W), Departament of General Jose de San Martin, Province of Salta, III-1991, TFS Nascimento and A Martinez colls., 35G, 40E, 40Le, 30L, 45Pe, 20GG, 10GE. An. cuyabensis (Neiva and Pinto, 1923) (= Anopheles triannulatus): lectotype female (n. 2027-IOC), Fazenda São João, State of Mato Grosso, VI-1922, C Pinto coll.

\section{DISCUSSION}

An. halophylus $\mathrm{n}$.sp. shares most of its morphological and morphometric characters in all life stages with $A n$. triannulatus, especially those related to the external features of the male, female and pupa. An. halophylus and An. triannulatus can be easily distinguished by characters of the male genitalia, setal forms and spiracular apparatus of 4th instar larva and general aspect of the egg. Regarding male genitalia, An. halophylus can be distinguished from An. triannulatus by the shape of the ventral lobe of the claspette (Fig. 1), especially by the form of the apicolateral lobes, which are broad and usually directed proximally in An. halophylus and moderately narrow and usually directed laterally or distally in $A n$. triannulatus. The 4th instar larva of An. halophylus has seta 1-P with very narrow, filiform branches, the lateral arms of median plate of the spiracular apparatus are rudimentary to completely absent and directed posteriorly, the distance between apices of lateral arms is 0.05-0.075 $\mathrm{mm}($ mean $=0.05)$, and the median plate of the spiracular apparatus is slightly narrowed proximally close to the insertion of lateral arms. In An. triannulatus seta 1-P has lanceolate leaflets, the lateral arms of median plate of the 
spiracular apparatus are well developed and directed laterally in an almost straight angle with the plate, the distance between the apices of lateral arms is around $0.1 \mathrm{~mm}$ $(0.08-0.11 \mathrm{~mm})$, and the median plate of the spiracular apparatus is strongly narrowed close to the insertions of the lateral arms. These species can also be distinguished in the live larva. In An. halophylus the abdominal and thoracic segments are somewhat uniformly greenish, with small whitish dots on the abdomen, whereas in $A n$. triannulatus there is a broad, roughly hexagonal, mesal spot composed by irregular and coalescent whitish and reddish brown spots on the thorax, and an irregular, longitudinal, mesal, broad stripe of coalescent whitish and reddish and yellowish brown spots on the abdomen, in addition to small lateral whitish dots. Egg of An. halophylus can be distinguished from An. triannulatus by the floats and the deck. In An. halophylus the floats correspond to nearly $60 \%$ of total length of the egg and the deck occupies about $50 \%$ of dorsal surface, whereas in An. triannulatus the floats are wide, extending almost from the anterior to the posterior ends, generally overlapping along the dorsal midline, sometimes completely covering the median and/or the posterior deck (Deane et al. 1947a, Lounibous et al. 1997).

Other secondary morphometric and morphological characters may also be useful to distinguish An. halophylus from An. triannulatus. Some morphometric differences observed between An. halophylus and An. triannulatus are statistically significant $(\mathrm{p}<0.05)$ : wing length (male: mean $=3.09 \mathrm{~mm}$; female: mean $=3.23 \mathrm{~mm}$ in An. triannulatus and male: mean $=2.75 \mathrm{~mm}$; female: mean $=2.84 \mathrm{~mm}$ in An. halophylus); dark scaling on foretarsomere 4 (female: 0.39-1.0, mean $=0.55$ in An. triannulatus and $1.0 \mathrm{in}$ An. halophylus); the frequency of foretarsomere 4 completely dark scaled varies from $10 \%$ in specimens from Argentina to 50\% in individuals from Central Brazil in An. triannulatus.

An. halophylus also showed to be biologically different from An. triannulatus by requiring sodium chloride for the development of larvae, suggesting preference for breeding in brackish water in nature. Additionally, these two species can also be distinguished by isoenzymatic analysis (unpublished data).

Both An. halophylus and An. triannulatus share several morphological and morphometric characters with two other forms of the An. triannulatus complex whose taxonomic status is under study using morphological, biochemical and molecular analyses. One form is sympatric with both An. halophylus and An. triannulatus s.s. in Central Brazil, being closely related to An. halophylus. The other form has been collected in Ecuador by ME Faran and R Wilkerson (pers. commun.), and shares most morphological characters with An. triannulatus s.s.

Indeed, among the four forms of the An. triannulatus complex, the only one that seems to occur throughout South and Central Americas is An. triannulatus s.s. Comparing specimens of An. triannulatus s.s. collected in the type-locality with specimens from several other localities in South America and the holotype we were able to confirm our hypothesis. In the type-locality of $A n$. triannulatus s.s., we found only specimens of $A n$. triannulatus s.s. as defined by Neiva and Pinto (1922) and redescribed by Faran (1980). Although some polymorphism has been detected, An. triannulatus s.s coincides with the form commonly collected throughout South and Central Americas.

Specimens of An. triannulatus s.s. are also morphologically indistinguishable from An. bachmanni described by Petrochi (1925) in all adult characters, especially the shape of the ventral lobe of claspette (fig. 5, p. 73 of original description). An. triannulatus s.s. is also identical with An. davisi Peterson and Shannon, 1927, An. perezi Shannon and Del Ponte, 1927 (the morphological characters of larvae and adults of both species clearly coincide with the An. triannulatus s.s. collected in its type-locality in Central Brazil) and An. triannulatus var. chagasi Galvão, 1941 (the range of variation in egg size and floats observed in An. triannulatus s.s. encompasses the form described for var. chagasi, e.g. Deane et al 1947a, Lounibos et al 1997). All these four names are considered junior synonym of An. triannulatus s.s. (Knight \& Stone 1977, Faran 1980, Ward 1984) and all are clearly distinct from An. halophylus n.sp. An. cuyabensis (Neiva and Pinto 1923) was demonstrated to be synonymous with $A n$. triannulatus by Pinto (1939) since morphological differences observed between females of these two species were demonstrated to represent intraspecific variation. The type-locality of An. cuyabensis is the same as that of An. triannulatus, a site where An. halophylus n.sp. has never been collected. As a result, none of the species names included in the synonymy of An. triannulatus (Knight \& Stone 1977, Ward 1984) could be resurrected to name the new taxon described herein.

Galvão (1940) and Galvão and Lane (1941) found in Salobra a distinct form of An. triannulatus s.l. According to these authors, this form could be distinguished from An. davisi in having larval seta 1-P with 20-23 filamentous branches, female with smaller wing and foretarsomere 4 completely dark-scaled. Since the type-locality of $A n$. triannulatus s.s. is in the geographical region of Salobra, Galvão (1940) and Galvão and Lane (1941) assumed that the distinctive form would correspond to An. triannulatus s.s. Consequently, these authors described two subspecies: An. triannulatus triannulatus, for the form discovered in Salobra, and An. triannulatus davisi Peterson and Shannon, 1927, for the common form found in other localities in South America. Although, Galvão and Lane (1941) did not examine immature stages from the type-locality of An. triannulatus s.s. As we stated, the larva of $A n$. triannulatus s.s. from the type locality is identical with that of An. davisi described by Peterson and Shannon (1927). Furthermore foretarsomere 4 entirely dark-scaled is not a useful character to separate species of the An. triannulatus complex, since we also observed it in females of $A n$. triannulatus s.s. collected in its type-locality and in southern and western Amazon Region in Brazil, and in Argentina including at the type-locality of An. davisi (unpublished data). Thus, An. triannulatus davisi Peterson and Shannon is synonymous with An. triannulatus s.s. Neiva and Pinto, whereas the distinctive form found in Salobra by Gavão (1940) and Galvão and Lane (1941) corresponds in part to An. halophylus n.sp. 


\section{ACKNOWLEDMENTS}

To NA Honório, RS Souza, DC Lima, MA Motta, CF Mendoza, JB Lima, SLB Luz, E Bergo, E Duarte, P Lounibous, J Conn and TA Klein, for help in the field work; TA Klein and United States Army Medical Research Unit-Brazil, M Póvoa and Instituto Evandro Chagas, Fundação Nacional de Saúde and A Martínez, Argentina, Salta and Grupo Empresarial Camargo Correia for support in collection and rearing of specimens.

\section{REFERENCES}

Charlwood JD, Wilkes TJ 1981. Observations on the biting activity of Anopheles triannulatus bachmanni from the Mato Grosso, Brazil. Acta Amazonica 11: 67-69.

Deane LM, Causey OR, Deane MP 1947a. Chave ilustrada para a identificação de ovos de trinta espécies de anofelinos brasileiros, com algumas descrições novas. Rev Serv Esp Saúde Públ 1: 293-308.

Deane LM, Causey OR, Deane MP 1947b. Chave ilustrada para a identificação de trinta e cinco espécies de anofelinos das regiões Nordestina e Amazônica do Brasil pelos caractéres da fêmea, com notas sobre os transmissores da malária (Diptera: Culicidae). Rev Serv Esp Saúde Públ 1: 309-336.

Deane LM, Causey OR, Deane MP 1948. Notas sobre a distribuição e a biologia dos anofelinos das regiões Nordestina e Amazônica do Brasil. Rev Serv Esp Saúde Públ 1: 827-965.

Faran ME 1980. Mosquito studies (Diptera, Culicidae). XXXIV. A revision of the Albimanus Section of the subgenus Nyssorhynchus of Anopheles. Contrib Amer Ent Inst 15: 1215.

Faran ME, Linthicum KJ 1981. A handbook of the Amazonian species of Anopheles (Nyssorhynchus) (Diptera: Culicidae). Mosq Syst 13: 1-81.

Forattini OP 1962. Entomologia Médica, Vol. 1, Univ. São Paulo, São Paulo, 662 pp.

Galvão ALA 1940. Contribuição ao conhecimento dos anofelinos do grupo Nyssorhynchus de São Paulo e regiões vizinhas (Diptera, Culicidae). Arq Zool 1: 399-484.

Galvão ALA 1941. Notas sobre alguns anofelinos do sub-gênero Nyssorhynchus do Norte do Brasil. Rev Biol Hyg 11: 92-96.

Galvão ALA 1943. Chaves para a determinação das espécies do subgênero Nyssorhynchus do Brasil. Arq Hig Saúde Públ 8: 141-153.

Galvão ALA, Lane J 1941. Observações sobre alguns anofelinos de Salobra, Mato Grosso (Diptera, Culicidae). Rev Biol Hyg 11: 10-18.

Harbach RE, Knight KL 1980. Taxonomist's Glossary of Mosquito Anatomy, Elsevier Pub., Amsterdam, 415 pp.

Knight KL, Stone A 1977. A Catalog of the Mosquitoes of the World (Diptera: Culicidae), Vol. 6, Thomas Say Foundation, Washington, $611 \mathrm{pp}$.

Lane J 1953. Neotropical Culicidae, Vol. 1, Univ. São. Paulo,
São Paulo, 548 pp.

Lourenço-de-Oliveira R, Luz SLB 1996. Simian malaria at two sites in the Brazilian Amazon. II . Vertical distribution and frequency of anopheline species inside and outside the forest. Mem Inst Oswaldo Cruz 91: 687-694.

Lourenço-de-Oliveira R, Guimarães AE, Arlé M, Silva TF, Castro MG, Motta MA, Deane LM 1989. Anopheline species, some of their habits and relation to malaria in endemic areas of Rondônia State, Amazon region of Brazil. Mem Inst Oswaldo Cruz 84: 501- 514.

Lounibos LP, Duzak D, Linley J 1997. Comparative egg morphology of six species of the Albimanus section of Anopheles (Nyssorhynchus) (Diptera: Culicidae). J Med Entomol 34: 136-155.

Neiva A, Pinto C 1922. Considerações sobre o gênero Cellia Theobald, com a descripção de uma nova espécie. Brazil Méd 36: 355-357.

Neiva A, Pinto C 1923. Sobre uma nova Anophelina brazileira (Cellia cuyabensis nov. sp.). Brazil Méd 37: 235-236.

Peterson GC, Shannon RC 1927. Mosquitos de Embarcación (Salta) con notas sobre la zona biológica del Chaco (Chaco Life Zone). $3^{\text {a }}$ Reunión Soc Arg Patol Reg Norte, Tucumán, 5 , p. 649-658.

Petrocchi J 1925. Descripción de un nuevo Anopheles. Rev Inst Bact, Buenos Aires, 4: 69-75.

Pinto C 1939. Disseminação da malária pela aviação. Biologia do Anopheles gambiae e outros anofelineos no Brasil. Mem Inst Oswaldo Cruz 34: 293-430.

Rosa-Freitas MG, Lourenço-de-Oliveira R, Pinto JCC, FloresMendoza C, Nascimento TFS 1998. Anopheline species complexes in Brazil. Current knowledge of those related to malaria transmission. Mem Inst Oswaldo Cruz 93: 651655.

Rubio-Palis Y 1994. Variation of the vectorial capacity of some anophelines in Western Venezuela. Am J Trop Med Hyg 50: 420-424.

Rubio-Palis Y, Wirtz RA, Curtis CF 1992. Malaria entomological inoculation rates in Western Venezuela. Acta Trop 52: 167-174.

Sallum AM, Schultz TR, Wilkerson RC 2000. Phylogeny of Anophelinae (Diptera Culicidae) based on morphological characters. Ann Entomol Soc Am 93: 745-775.

Shannon RC, Del Ponte E 1927. Los culicidios en la Argentina. Rev Inst Bact, Buenos Aires, 5: 29-140.

Valle D, Monnerat A, Soares MJ, Rosa-Freitas MG, PelajoMachado M, Vale BS, Lenzi HL, Galler R, Lima JBP 1999. Mosquitos embryos and eggs: polarity and terminology of chorionic layers. J Insect Physiol 45: 701-708.

Ward RA 1984. Second supplement to "A catalog of the mosquitoes of the world (Diptera: Culicidae)". Mosq Syst 16: 227-270.

Wilkerson RC, Peyton EL 1990. Standardized nomenclature for the costal wing spots of the genus Anopheles and other spotted-wing mosquitoes (Diptera: Culicidae). J Med Entomol 27: 217-224. 